\title{
ANALISIS IMPLEMENTASI PENYANDERAAN (GIJZELING) DALAM MENINGKATKAN KEPATUHAN WAJIB PAJAK DAN SEBAGAI UPAYA PENCAIRAN TUNGGAKAN PAJAK: MENURUT PERSPEKTIF TEORI KEPATUHAN PAJAK (Studi Kantor Wilayah DJP Jawa Tengah I)
}

\author{
Respati Dian Cahyaa ${ }^{a}$ Endang Kiswara ${ }^{b}$ Fuad $^{c}$ \\ a Direktorat Jenderal Pajak. Email: respati.diancahya@pajak.go.id \\ b Universitas Diponegoro, Semarang. Email: feb@undip.ac.id \\ c Universitas Diponegoro, Semarang. Email: feb@undip.ac.id
}

\section{ABSTRACT}

This study aims to analyze and evaluate the implementation of gijzeling. This study also analyzes whether there are differences in impacts before and after the implementation of gijzeling on taxpayer compliance who is subject to gijzeling action, and analyzes whether the implementation of gijzeling provides deterrent effect for taxpayers subject to gijzeling action and other taxpayers in terms of taxpayer compliance and disbursement of tax arrears in Regional Office of DGT Central Java I. The data obtained were analyzed using a descriptive qualitative research method with a case study approach to answering the research question. The result of the research concludes that the implementation of gijzeling has been run in accordance with the provisions of the law, although in the field process, there are some adaptations and development, but still based on the procedures and rules. The implementation of gijzeling also made 100\% liquid tax arrears for taxpayers subject to gijzeling action, while the application of gijzeling also proved to create a deterrent effect for other taxpayers who are in 1 group of companies that have tax arrears. The implementation of gijzeling in 2016 has not had any impact on tax arrears through other active collection.

Keywords: gïzeling, tax arrears, deterrent effect, tax compliance, law enforcement

\section{ABSTRAK}


Penelitian ini bertujuan untuk menganalisis dan mengevaluasi implementasi gijzeling. Penelitian ini juga menganalisis adakah perbedaan dampak sebelum dan sesudah implementasi gijzeling terhadap kepatuhan wajib pajak (WP) yang di-gijzeling, serta menganalisis apakah implementasi gijzeling memberikan efek jera bagi WP yang di-gïzeling maupun WP lain dari segi kepatuhan WP dan pencairan tunggakan pajak di Kantor Wilayah DJP Jawa Tengah I. Data yang diperoleh dianalisis menggunakan metode penelitian kualitatif deskriptif dengan pendekatan studi kasus untuk manjawab partanyaan penelitian. Hasil penelitian diperoleh kesimpulan bahwa pelaksanaan gijzeling sudah berjalan sesuai ketentuan undang-undang, meskipun dalam proses di lapangan terdapat adaptasi maupun pengembangan, tetapi tetap berdasarkan pada prosedur dan aturan. Pelaksanaan gijzeling berhasil membuat tunggakan pajak cair 100\% bagi WP yang di-gïzeling, selain itu penerapan gijzeling juga terbukti dapat menciptakan efek jera bagi WP lain yang berada dalam 1 (satu) grup perusahaan yang punya tunggakan pajak. Pelaksanaan gijzeling di tahun 2016 belum membawa dampak terhadap tunggakan pajak melalui penagihan aktif lainnya.

Kata kunci: gijzeling, tunggakan pajak, efek jera, kepatuhan perpajakan, penegakan hukum

\section{PENDAHULUAN}

\subsection{Latar Belakang}

Pajak adalah sumber pendapatan negara terbesar yang digunakan untuk pembayaran atas pengeluaran pemerintah dalam rangka pembangunan Indonesia. Mengingat pentingnya sumber pendapatan negara tersebut bagi kelangsungan pembangunan, maka target penerimaan pajak di Indonesia terus meningkat dari tahun ke tahun.

Untuk menjawab tantangan tersebut, Direktorat Jenderal Pajak (DJP), sebagai instansi pemerintah yang mengemban amanah untuk menghimpun pendapatan pajak, membuat Rencana Strategis (Renstra) DJP Tahun 2015-2019 melalui Kepdirjen Pajak Nomor: KEP-95/PJ/2015. Di dalam dokumen perencanaan strategis jangka menengah untuk periode 5 (lima) tahun tersebut, DJP menentukan arah kebijakan setiap tahunnya agar peneriman negara meningkat. Pada awal periode Renstra di tahun 2015, DJP mencanangkan "Tahun Pembinaan", dan dilanjutkan tahun 2016 sebagai "Tahun Penegakan Hukum". Berjalannya "Tahun Penegakan Hukum" mengakibatkan fasilitas dan kemudahan dalam membetulkan laporan pajak yang diberikan pada tahun 2015 tidak dapat digunakan kembali. Sebagai gantinya DJP akan fokus pada langkah-langkah penegakan hukum.

Salah satu kebijakan pemerintah dalam penegakan hukum di bidang perpajakan yang menjadi pembahasan menarik adalah 
tindakan gïzeling. Isu ini menarik karena cara penagihan aktif (hard collection) yang sebelumnya jarang sekali dilakukan, namun pada tahun 2015 dan 2016 dilakukan secara intensif dan merata di berbagai wilayah Indonesia. Hal ini dilakukan untuk memberikan efek jera bagi penunggak pajak agar segera membayar utang pajaknya.

Secara garis besar, jumlah piutang pajak yang cenderung semakin besar nilainya menjadikan DJP mulai menerapkan gïzeling sebagai upaya final dalam penagihan pajak yang bermuara kepada pencairan piutang pajak. Namun, dampak gijzeling terhadap peningkatan kepatuhan pajak dan penurunan jumlah piutang pajak di tahuntahun berikutnya belum dapat disimpulkan sehingga perlu dilakukan penelitian lebih lanjut.

Dalam studi terdahulu, pelaksanaan gïzeling terbukti memberikan pengaruh positif bagi penerimaan perpajakan dan kepatuhan WP sebagaimana penelitian yang dilakukan oleh Rahaviadhy (2004). Berdasarkan penelitiannya, kebijakan gïzeling tidak hanya bersifat penegakan hukum di bidang perpajakan saja, tetapi juga memberi pesan moral sebagai efek jera bagi para penunggak pajak yang lain, disamping itu gijzeling berpengaruh besar terhadap penerimaan pajak, yaitu pencairan tunggakan pajak hampir 30\% terealisasi.

Penelitian tersebut sejalan dengan riset yang dilakukan oleh Putri (2008) mengenai gijzeling sebagai upaya pencairan tunggakan pajak. Hasil studi tersebut mengungkapkan bahwa gijzeling memengaruhi penunggak pajak untuk membayar tunggakan pajaknya dan dampak gijzeling dalam pencairan tunggakan pajak periode 2003 hingga 2005 dikatakan sukses karena berpengaruh cukup signifikan dalam meningkatkan penerimaan pajak.

Lain halnya penelitian Lucia (2009) yang menemukan bahwa dari segi penerimaan pajak, penerapan gijzeling dirasa kurang efektif, meskipun dari segi peningkatan kepatuhan pajak penerapan gijzeling dapat dikatakan berpengaruh positif. Penelitian terbaru terkait gijzeling dilakukan oleh Veronica dkk. (2015), yang menemukan bahwa pencairan tunggakan pajak melalui gijzeling berhasil terealisasi 100\%, tetapi gijzeling belum dapat menciptakan efek jera bagi WP lain karena hanya memberikan efek jera kepada WP yang disandera.

Berbeda dengan beberapa hasil riset tersebut, Wahyumurti (2005) dan Wismono (2006) menengarai adanya hubungan yang justru negatif atau belum cukup untuk dikatakan sebagai hal yang dapat meningkatkan kesadaran WP dalam memenuhi kewajiban perpajakan. Hal ini bisa saja terjadi ketika gïzeling atau hukuman penjara karena utang pajak dilakukan tanpa kaidah dan peraturan yang seharusnya sehingga menimbulkan antipati masyarakat apabila tidak dilakukan dengan 
memenuhi azas keadilan seperti pada penelitian Epstein (1998), Epstein dkk. (2011) dan Kubiak (2012).

Penelitian lain yang menyoroti segi implementasi gïzeling dilakukan oleh Norma dkk. (2016) yang menyatakan bahwa terdapat hambatan-hambatan dalam proses pelaksanaan gijzeling di Kantor Wilayah (Kanwil) DJP Jawa Tengah (Jateng) I dan Kanwil DJP Jateng II.

Berdasarkan hasil dari penelitian sebelumnya yang tidak konsisten dan bahkan kontradiktif, serta adanya indikasi hambatan pelaksanaan gijzeling maka penulis merumuskan masalah pada penelitian ini dalam bentuk pertanyaan sebagai berikut:

1. Bagaimana implementasi gijzeling di Kanwil DJP Jateng I?

2. Bagaimanakah perbedaan dampak sebelum dan sesudah dari implementasi gïzeling terhadap kepatuhan WP yang di-gïzeling di Kanwil DJP Jateng I?

3. Apakah implementasi gïzeling memberikan efek jera bagi WP yang digïzeling maupun WP lain dari segi kepatuhan WP dan pencairan tunggakan pajak di Kanwil DJP Jateng I?

\section{KERANGKA TEORITIS DAN MODEL PENELITIAN}

\subsection{Teori Kepatuhan Perpajakan (Tax Compliance Theory)}

Menurut Nurmantu (2005), kepatuhan pajak adalah suatu keadaan dimana WP memenuhi dan mematuhi semua kewajiban perpajakan serta melaksanakan hak perpajakannya. Kepatuhan berdasarkan jenisnya terdiri dari kepatuhan formal dan kepatuhan material (Nurmantu, 2005).

Definisi ini sangat berguna untuk memahami kerangka self assesment system, di mana kepatuhan WP, baik ditinjau dari segi formal maupun material, diarahkan pada timbulnya kepatuhan yang bersifat sukarela (voluntary compliance) dan bukan kepatuhan yang dipaksakan (compulsary compliance). Dengan timbulnya kepatuhan pajak yang bersifat sukarela, diharapkan upaya fiskus menjadi semakin efisien dalam menjaga penerimaan pajak karena WP dengan sadar melakukan kewajibannya tanpa ada paksaan.

Rahayu (2010) memberikan indikator dalam mengukur kepatuhan WP dalam melaksanakan kewajibannya yang dapat dilihat dari:

1. kepatuhan WP dalam mendaftarkan dirinya ke kantor pajak;

2. kepatuhan WP untuk menyampaikan surat pemberitahuan (SPT);

3. kepatuhan dalam penghitungan dan pembayaran pajak terutang; dan

4. kepatuhan dalam pembayaran tunggakan.

DJP sendiri mendefinisikan WP Patuh berdasarkan PMK No.192/PMK.03/2007 yang diperbarui dengan PMK 
No.74/PMK.03/2012 tentang Tata Cara Penetapan dan Pencabutan Penetapan WP dengan Kriteria Tertentu dalam Rangka Pengembalian Pendahuluan Kelebihan Pembayaran Pajak, yaitu WP sebagai berikut:

1. tepat waktu dalam menyampaikan SPT;

2. tidak mempunyai tunggakan pajak untuk semua jenis pajak, kecuali tunggakan pajak yang telah memperoleh izin mengangsur atau menunda pembayaran pajak;

3. Laporan Keuangan diaudit oleh Akuntan Publik atau lembaga pengawasan keuangan pemerintah dengan pendapat Wajar Tanpa Pengecualian selama 3 (tiga) tahun berturut-turut; dan

4. tidak pernah dipidana karena melakukan tindak pidana di bidang perpajakan

berdasarkan putusan pengadilan yang telah mempunyai kekuatan hukum tetap dalam jangka waktu 5 (lima) tahun terakhir.

Kepatuhan pajak secara lebih komprehensif dijelaskan juga oleh Posner (2000) yaitu ketika WP memutuskan apakah membayar pajaknya, WP akan memperhitungkan besarnya pajak tersebut dan sanksi legal yang diterima dari ketidakpatuhan. James dan Alley (1999) menjelaskan lebih jauh mengenai kepatuhan pajak ini dengan merujuk pada bagaimana sikap pembayar pajak yang memiliki rasa tanggung jawab sebagai warga negara bukan hanya sekedar takut akan sanksi dari hukum pajak yang berlaku. Pendapat serupa dinyatakan oleh James dan Nobes (1997) yang mengemukakan bahwa kepatuhan pajak dapat dijelaskan sebagai tingkatan WP dalam memenuhi hukum pajak. Oleh karena itu, derajat ketidakpatuhan dapat diukur dengan berapa besar kesenjangan pajak (tax gap) yang terjadi. Tax gap merujuk pada perbedaan antara penerimaan pajak yang diterima (actual revenue) dengan apa yang seharusnya diterima jika WP patuh 100\%.

\subsection{Penegakan Hukum dalam Kepatuhan Perpajakan}

Kirchler (2007) mengusulkan sebuah konsep teoritis sebagai penentu kepatuhan pajak yang disebut teori kerangka Slippery Slope yang mengintegrasikan faktor ekonomis dan psikologis. Teori kerangka slippery slope terdiri dari dimensi kepercayaan otoritas pajak, kekuasaan otoritas pajak, dan pembayaran pajak. Pembayaran pajak diasumsikan dipengaruhi oleh kepercayaan dan kekuasaan otoritas. Jika kepercayaan dan kekuasaan berada pada tingkat minimum, pembayaran pajak diasumsikan rendah karena WP bertindak secara egois dengan memaksimalkan keuntungan mereka melalui penghindaran pajak. Jika kepercayaan otoritas meningkat maka pembayar pajak juga diasumsikan meningkat. Selain itu, jika kekuasaan otoritas 
pajak meningkat, pembayaran pajak yang diperkirakan akan meningkat juga.

Lebih lanjut Kirchler (2007) menjelaskan bahwa kepatuhan pajak tergantung pada iklim integrasi faktor ekonomis dan psikologis antara pemerintah dan pembayar pajak. Masyarakat perlu penegakan hukum agar mereka mematuhi perpajakan atau mereka dapat bekerja sama secara sukarela. Kepatuhan pajak diasumsikan tergantung pada kekuasaan otoritas dan kepercayaan warga negara dalam wewenang pemerintah. Probabilitas audit dan denda merupakan hal yang penting untuk mengatur perilaku masyarakat, begitu juga keadilan distribusi dari beban pajak yang dibayar, kesetaraan prosedur, dan norma sosial.

Ketentuan perpajakan, baik yang bersifat substansial maupun prosedural, pada hakikatnya diarahkan kepada peningkatan kepatuhan pajak. Secara umum, terdapat banyak aspek dalam meningkatkan kepatuhan perpajakan, termasuk didalamnya membuat aturan hukum yang adil, mudah untuk dipatuhi, dan sulit untuk dihindari. Namun, salah satu aspek penting yang harus diperhatikan adalah mengenai ketentuan sanksi atas ketidakpatuhan dalam kewajiban perpajakan (Gordon, 1996).

Sanksi merupakan instrumen yang sangat diandalkan dalam meningkatkan kepatuhan pada sistem perpajakan. Salah satu tujuan dalam mengenakan sanksi pajak adalah untuk mengubah perilaku yang tidak diinginkan dari WP seperti upaya penghindaran pembayaran pajak (Gordon, 1996). Dengan demikian, pengenaan sanksi merupakan upaya untuk memberikan efek jera terhadap perilaku yang tidak diinginkan. Selain itu, sanksi yang dikenakan haruslah proporsional dengan tingkat kesalahannya. Misalnya, sanksi tidak ditujukan bagi subjek pajak yang melakukan kekeliruan yang tidak berdampak pada kekurangan pembayaran pajak pada waktunya.

Becker (1968) menyebutkan bahwa denda merupakan sanksi yang memiliki keuntungan dibanding jenis-jenis sanksi lain seperti penyanderaan, pemenjaraan, pembebasan bersyarat dan sebagainya. Selanjutnya Becker (1968) mengemukakan bahwa sanksi berupa denda akan menghemat anggaran dalam rangka penyediaan penjara, gaji sipir, gaji polisi dan sebagainya sehingga denda ini dapat mengkompensasi kerugian masyarakat akibat pelanggaran yang telah dilakukan.

Becker (1968) juga menjelaskan apabila pelanggar ini tidak memiliki dana untuk membayar denda tidak serta merta ia akan dibebaskan akan tetapi hukuman bagi pelanggar tersebut akan berubah jenisnya. "Hukuman tersebut bisa berbentuk penyanderaan, penyitaan, ataupun pemenjaraan" (Becker, 1968).

Penyanderaan pada dasarnya memiliki tujuan yang sama dengan bentuk-bentuk sanksi yang lain, yakni mendorong WP agar 
melunasi utang pajaknya. Selain itu, penyanderaan dapat menjadi sarana untuk menyebarkan efek jera bagi WP lainnya guna menumbuhkan kesadaran dan meningkatkan kepatuhan dalam memenuhi kewajiban perpajakannya.

Shavell (1985) menjelaskan apabila biaya (cost of noncompliance) yang dikenakan lebih besar dari gain atau kepuasan (savings from noncompliance) yang diperoleh maka WP cenderung memutuskan untuk membayar tunggakan pajak, dan sebaliknya. Shavell (1985) mengungkapkan dengan demikian perilaku ini akan cenderung mengarahkan WP untuk tidak membayar tunggakan pajak jika manfaat yang diperoleh lebih besar daripada total hukuman yang akan dikenakan kepadanya. Perilaku ini berhubungan juga dengan perilaku WP yang menyukai risiko yang cenderung memilih untuk kembali ke perilaku ketidakpatuhannya jika pernah terancam digïzeling pada suatu periode dan memiliki informasi, misalnya tentang keterbatasan ruangan yang digunakan untuk gijzeling. Informasi tersebut memberi keyakinan bahwa tindakan gijzeling hanya dilakukan selama periode tertentu saja. Oleh karena itu, gijzeling akan efektif dan menimbulkan efek jera apabila dilakukan secara konsisten.

\subsection{Kerangka Model Penelitian}

Kerangka pemikiran penelitian dapat dijabarkan dalam sebuah model penelitian sebagaimana diilustrasikan di Gambar 1 pada lampiran.

\section{METODOLOGI PENELITIAN}

Penelitian ini dirancang dengan menggunakan metode penelitian kualitatif deskriptif guna menjawab pertanyaan penelitian. Menurut Finlay (2006), penelitian kualitatif adalah penelitian yang dilakukan dalam pengaturan tertentu yang ada dalam kehidupan riil (alamiah) dengan maksud menginvestigasi dan memahami fenomena, apa yang terjadi, mengapa terjadi, bagaimana terjadi, dan berbasis pada konsep yang menjelajahi serta melibatkan studi yang mendalam dan berorientasi kasus atas sejumlah kasus atau kasus tunggal. Dalam pengertian, penulis bermaksud mengambarkan dan melaporkan secara rinci, sistematis, dan menyeluruh mengenai segala sesuatu yang berkaitan dengan pelaksaaan ketentuan gijzeling serta implikasinya terhadap kepatuhan WP.

\subsection{Lokasi dan Waktu Penelitian}

Lokasi penelitian ini adalah Kanwil DJP Jateng I dengan melihat KPP Pratama yang memiliki kasus penagihan pajak dengan menerapkan gïzeling. Waktu penelitian adalah pada bulan Januari 2017 s.d. Oktober 2017, dengan alokasi waktu dan 
kegiatan yang sudah dibagi menurut kebutuhan penelitian.

\subsection{Metode Pengumpulan Data}

\subsubsection{Wawancara}

Pemilihan informan penelitian dilakukan terhadap orang yang merupakan pelaku kunci dalam penerapan penagihan pajak dengan cara gijzeling, yaitu:

1. Kepala Seksi dan Pelaksana Seksi Bimbingan Penagihan Kanwil DJP Jateng I.

2. Kepala Seksi Penagihan, Juru Sita, Kepala Seksi Pengawasan dan Konsultasi, dan Account Representative (AR) di KPP Pratama.

Sedangkan pemilihan informan penelitian untuk menangkap realitas respons dari WP yang bisa digali terkait penerapan penagihan pajak dengan cara gïzeling di Kanwil DJP Jateng I, yaitu WP lain, konsultan pajak, dan akademisi.

Dalam penelitian ini, peneliti tidak berhasil mendapat informan utama yaitu WP yang dikenai tindakan gïzeling dalam kasus penagihan pajak di Kanwil DJP Jateng I. Hal tersebut dikarenakan:

1. Peneliti tidak mendapat ijin dari DJP terkait pengungkapan WP yang dikenakan tindakan gïzeling di Kanwil DJP Jateng I.

2. Data WP yang dikenakan tindakan gijzeling bersifat rahasia sehingga tidak dapat diungkapkan kepada umum.

\subsubsection{Observasi/Pengamatan}

Teknik observasi yang digunakan adalah terus terang atau tersamar. Peneliti melakukan pendekatan personal kepada sumber data dengan cara mengamati sikap, motivasi, opini, ekspektasi atau intensi dari sumber data, yaitu:

1. Respons informan dalam pelaksanaan ketentuan gijzeling untuk peningkatkan kepatuhan WP pada Kanwil DJP Jateng I.

2. Dampak dari gijzeling yang dihasilkan setelah diterapkan di Kanwil DJP Jateng I.

\subsubsection{Analisis Dokumen}

Analisis deskriptif dari data sekunder yang diperoleh dari dokumentasi pelaksanaan gijzeling di Kanwil DJP Jateng I. Data sekunder lainnya yang berkaitan dengan data penagihan dan kepatuhan WP, serta peraturan atau petunjuk teknis pelaksanaan ketentuan gijzeling yang mendukung penelitian.

\subsection{Teknik Analisis}

Data yang diperoleh pada dasarnya merupakan data tataran yang dianalisis secara deskriptif kualitatif, yaitu data yang terkumpul dituangkan dalam bentuk uraian logis dan sistematis yang menghubungkan fakta yang ada dengan berbagai peraturan yang berlaku. Analisa akan dituangkan dalam bentuk kalimat yang ringkas dan 
jelas. Menurut Miles dan Huberman (2007) analisis dalam penelitian kualitatif terdiri dari tiga tahap, yaitu: 1) tahap reduksi data; 2) tahap penyajian data; dan 3) tahap penarikan kesimpulan dan verifikasi data.

\section{HASIL DAN PEMBAHASAN}

\subsection{Analisis Implementasi dan Evaluasi Gijzeling di Kanwil DJP Jateng I}

\subsubsection{Persepsi yang Telah Terbentuk}

Persepsi yang sering dianalogikan sebagai pandangan ataupun anggapan, dilihat Robbins (2001) sebagai sebuah proses yang dilakukan individu untuk mencerna dan menafsirkan kesan yang dapat ditangkap oleh indera dalam rangka memberi makna kepada lingkungannya. Persepsi yang telah terbentuk di benak informan dalam penerapan gijzeling oleh Kanwil DJP Jateng I adalah penerapan gijzeling memberi dampak positif. Sebanyak 13 informan setuju jika gijzeling diterapkan dalam penagihan pajak karena pelaksanaannya telah diatur dalam Undang-undang. Dari hasil wawancara mendalam kepada informan diperoleh beberapa alasan kenapa informan menyetujuinya.

Alasan pertama, gïzeling sebagai salah satu alat penagihan aktif untuk meningkatkan pencairan tunggakan pajak terhadap Penanggung Pajak yang memenuhi syarat kuantitatif, yaitu Penanggung Pajak mempunyai utang pajak sekurang-kurangnya Rp100.000.000,00 yang meliputi semua jenis pajak dan tahun pajak. Jumlah tersebut menunjukkan bahwa gijzeling tidak ditujukan kepada Penanggung Pajak yang berpenghasilan kecil.

Hasil persepsi dari informan sejalan dengan teori kepatuhan pajak oleh James dan Nobes (1997) yang mengemukakan bahwa kepatuhan dapat dijelaskan sebagai tingkatan WP dalam memenuhi hukum pajak. Pendapat yang diberikan informan sebenarnya sudah mengungkapan tingkatan-tingkatan dalam penagihan pajak, namun apabila ternyata WP masih belum memenuhi kewajibannya, perlu tindakan terakhir yaitu gïzeling, yang menurut informan adalah senjata utama dalam penagihan.

Alasan kedua kenapa gïzeling perlu dilakukan, yaitu sebagai shock therapy yang diharapkan akan memberikan efek jera terhadap Penanggung Pajak lainnya. Salah satu contoh kasus terdapat di KPP Pratama Kudus. Ketika salah satu WP dikenakan gijzeling, WP lain dalam grup-nya yang mempunyai tunggakan pajak juga membayar utang pajaknya. Artinya, implementasi gïzeling terbukti memberikan efek jera terhadap Penanggung Pajak lainnya. Dari kasus tersebut terlihat bahwa esensi dari penerapan gijzeling juga sebagai salah satu cara untuk memberikan edukasi kepada WP yang lain.

Pandangan akan kepatuhan pajak yang diutarakan informan mencerminkan sikap 
dan perilaku WP yang hampir serupa dengan yang diutarakan James dan Alley (1999) yang menjelaskan lebih jauh mengenai kepatuhan pajak ini dengan merujuk pada bagaimana sikap pembayar pajak yang memiliki rasa tanggung jawab sebagai warga negara, bukan hanya sekedar takut akan sanksi dari hukum pajak yang berlaku.

Alasan ketiga dari keterangan informan penerapan gijzeling adalah untuk meningkatkan kepatuhan WP/Penanggung Pajak dalam membayar pajak, meningkatkan keadilan dalam pemungutan pajak, dan melaksanakan penegakan hukum dalam pelaksanaan pemungutan pajak secara konsisten. Perlu dipahami bahwa pelaksanaan penegakan hukum di bidang perpajakan merupakan salah satu tugas dari DJP sehingga penerapan gijzeling yang dilakukan secara luas pada tahun 2015 dan 2016 ini dapat membuka mata WP bahwa DJP berkomitmen dalam pelaksanaan penegakan hukum dan diharapkan dapat meningkatkan kepatuhan WP/Penanggung Pajak dalam membayar pajak.

Hal tersebut sejalan dengan teori yang diungkapkan oleh Kirchler (2007) dalam teori kerangka slippery slope, dimana jika kekuasaan otoritas pajak meningkat, pembayaran pajak yang diperkirakan akan meningkat juga. Kekuasaan yang dimaksud disini adalah kewenangan KPP Pratama dalam melaksanakan upaya terakhir dalam penagihan, yaitu gijzeling agar kepatuhan
WP meningkat dengan adanya penegakan hukum.

Kesimpulan persepsi informan terhadap gijzeling yang telah terbentuk adalah bahwa penerapan gijzeling harus dilakukan secara selektif kepada WP yang mempunyai tunggakan pajak. Fiskus harus melihat aspek kemampuan membayar dari WP yang mampu dan ada kewajiban untuk membayar, yang mana hal tersebut merupakan aspek yang paling penting. Hal ini karena WP yang punya utang pajak tidak serta-merta langsung semua dilakukan gijzeling, harus berdasarkan skala prioritas. Di samping itu, pelaksanaannya juga harus sesuai dengan aturan dan prosedur yang berlaku, sehingga tidak menimbulkan gugatan hukum dari WP/Penanggung Pajak.

\subsubsection{Sikap dan Partisipasi Pelaku/Informan}

Sikap dipandang sebagai kesiapan untuk bereaksi terhadap suatu obyek dengan cara-cara tertentu, sebagai wujud penghayatan terhadap obyek tersebut. Namun Notoatmodjo (2003) beranggapan bahwa sikap belum diakui sebagai sebuah gerakan atau langkah nyata, tapi masih berupa predisposisi tindakan dari tingkah laku individu atau masih berupa reaksi yang tertutup. Sedangkan partisipasi diartikan sebagai ikut sertanya individu secara sadar ke dalam interaksi sosial dalam situasi tertentu. 
Penerapan gïzeling di Kanwil DJP Jateng I ditanggapi berbagai macam sikap dan partisipasi oleh para informan, namun secara garis besar semua informan memandang gïzeling memberi dampak positif. Adapun gambaran sikap dan partisipasi yang diperoleh dari informan sebagai berikut:

1. Sikap mendukung gïzeling karena dianggap mampu memenuhi tuntutan dalam penegakan hukum, pencairan piutang, dan memberikan efek jera terhadap Penanggung Pajak lainnya. Hal tersebut terjadi dalam praktik di lapangan dimana pada kasus gïzeling di KPP Pratama Kudus, gijzeling memberikan efek jera terhadap Penanggung Pajak lainnya.

2. Sikap mendukung penerapan gijzeling dengan pertimbangan adanya tuntutan dari Kantor Pusat DJP di tahun 2016 dengan arah kebijakannya berupa "Tahun Penegakan Hukum". Dengan berjalannya "Tahun Penegakan Hukum", maka masing-masing KPP pratama berusaha untuk memenuhi tuntutan IKU yang diberikan oleh Kanwil DJP Jateng I di tahun 2016. Sedangkan di tahun 2017 terdapat IKU yang harus diusulkan oleh masing-masing KPP dalam hal usulan gelar perkara untuk memperkuat partisipasi para informan penerapan gïzeling, data usulan gelar perkara penyanderaan di lingkungan Kanwil DJP Jateng I tersaji di Tabel 1 pada lampiran.
3. Terdapat pandangan dari informan terkait pelaksanaan gijzeling dengan usulan IKU gelar perkara di tahun 2017 yang dalam pelaksanaannya dianggap tidak efektif, karena hampir sebagian besar WP mengikuti program Tax Amnesty sehingga utang pajak yang lampau otomatis dihapuskan karena WP ikut program tersebut. Karena karakter dari informan mendukung dan melaksanakan program organisasi, pelaksanaan IKU tetap dilaksanakan.

4. Dalam mendukung komitmen penerapan gijzeling, persiapan yang dilakukan oleh organisasi DJP mencangkup pemberian edukasi berupa sosialisasi kepada WP dan penyediaan sarana serta prasarana. Di samping melakukan sosialisasi secara massal kepada WP, fiskus juga mengundang secara personal WP yang mempunyai tunggakan pajak, sehingga konsultasi berfokus dan intens terkait dengan penagihan pajak.

5. Banyak cara yang bisa dilakukan fiskus dalam memberikan edukasi berkaitan dengan penagihan terutama tentang gijzeling. Adapun kegiatannya menurut penjelasan para informan adalah:

a. Kegiatan sosisalisasi dengan cara menempelkan berita yang berasal dari surat yang berkaitan dengan pelaksanaan gïzeling di ruang konsultasi penagihan dan bagian 
pelayanan di lingkungan kerja masing-masing.

b. Kegiatan sosisalisasi juga dilakukan fiskus saat turun ke lapangan, saat menyampaikan surat teguran, dan saat menyampaikan surat paksa kepada WP. Dalam menyampaikan surat paksa, fiskus melakukannya secara persuasif dan menerangkan secara individu dan secara personil kepada Penanggung Pajak.

c. Fiskus juga dapat mensosialisasikan program Tax Amnesty kepada WP yang akan dikenai gijzeling, sehingga mereka dapat memanfaat fasilitas yang diberikan pemerintah terkait dengan pajak-pajaknya yang telah lampau dan tidak benar dalam pelaporan.

6. Persiapan yang dilakukan Kanwil DJP Jateng I merupakan cerminan dari sikap mendukung penerapan gïzeling. Peningkatan kompetensi Sumber Daya Manusia (SDM) mutlak diperlukan, karena dalam penerapan gïzeling dibutuhkan pemahaman yang mendalam untuk mengeksekusi sebuah kasus gijzeling. Namun realitas yang terjadi di lapangan, diperoleh informasi dari salah seorang informan bahwa informan belum pernah menerima sosialisasi yang khusus berkaitan dengan gijzeling dari unit vertikal. Sehingga salah satu cara untuk menambah pengetahuannya tentang aturan gijzeling, yaitu dengan membaca dan memahami sendiri aturan perpajakan.

7. Instansi Kanwil DJP Jateng I bukan tanpa usaha dalam meningkatkan kompetensi fiskus terkait gïzeling. Upaya peningkatan kompetensi SDM dilakukan oleh Kanwil DJP Jateng I di tahun 2017 dengan cara mengundang para pejabat struktural eselon IV untuk menghadiri sosialisasi pembahasan mengenai aturan perpajakan terbaru dan penerimaan pajak yang terdiri dari penggalian potensi pajak dan extra effort serta membahas penegakan hukum dan langkah-langkah DJP setelah program Tax Amnesty.

8. Bentuk dukungan lain Kanwil DJP Jateng I terkait penerapan gijzeling yaitu penyediaan sarana dan prasarana. Penerapan gïzeling merupakan kerja sama tim, di mana ada transfer knowledge antara koordinator, yaitu Kanwil DJP Jateng I, dengan eksekutor yaitu KPP Pratama, dan bagian dukungan yang diamanahkan kepada Kanwil Kemkum dan HAM Jateng, Direktorat Reskrimsus Polda Jateng, dan tenaga medis di RSUD masing-masing.

Kesimpulan dari keseluruhan sikap dan partisipasi informan terkait dengan kasus gijzeling ini untuk SDM maupun sarana dan prasarana, sudah cukup baik karena Kepala Seksi Penagihan dan Juru Sita di KPP Pratama tidak bekerja sendiri, tapi bekerja secara tim dengan pihak lainnya untuk 
kegiatan gïzeling. Yang perlu digarisbawahi disini, yaitu meskipun dari segi SDM dan sarana serta prasarana sudah cukup, namun kerja sama dengan instansi lain mutlak diperlukan untuk mendukung suksesnya kegiatan gijzeling.

\subsubsection{Permasalahan dalam Penerapan Gijzeling}

Terdapat beberapa permasalahan di lapangan yang dihadapi informan dalam penerapan gïzeling yang terdiri dari 7 (tujuh) hal, yaitu:

1. Dalam implementasi gijzeling, permasalahan justru timbul di lingkup internal, yaitu terdapat keraguan dari salah satu Kepala Kantor yang kurang siap dalam penerapan gïzeling. Hal tersebut dapat diatasi dengan cara memberikan pemahaman sepenuhnya kepada pimpinan dan memberi jaminan bahwa semua elemen sudah diperhitungkan baik dari segi SDM, sarana dan prasarana, mitigasi risiko, maupun legalitas terkait dengan aturan hukum sehingga memitigasi risiko terjadinya gugatan hukum dari WP.

2. Belum adanya Daftar Isian Pelaksanaan Anggaran (DIPA) khusus untuk pelaksanaan gijzeling di Kanwil DJP Jateng I. Hal ini menyebabkan dana untuk pengawalan polisi/biaya pengamanan menjadi cukup tinggi. Dari pengalaman gijzeling di tahun 2016, Kanwil DJP Jateng I mengajukan DIPA khusus di tahun 2017 untuk kegiatan gijzeling dan dananya sudah tersedia.

3. Karena baru terbentuk, seksi intelijen pada saat itu belum memiliki anggaran pengadaan barang untuk alat-alat penunjang pekerjaan, contohnya alat penyadap. Meskipun demikian, budaya kerja yang mendukung perubahan dan adanya kemauan untuk mengembangkan diri membuat petugas intelijen membeli sendiri alat-alat penunjang pekerjaan dari anggaran pribadi.

4. Fiskus mempertimbangkan adanya "backing" dari WP yang akan di gijzeling. Namun dalam praktiknya, hal yang dikhawatirkan tidak terjadi dan gijzeling sukses dilaksanakan.

5. Proses eksekusi WP yang akan dilakukan gijzeling perlu dijadwal ulang kembali sebab target operasi sempat lolos dari pengamatan atau terjadi penolakan dari WP yang akan dilakukan gijzeling. Namun demikian, fiskus di lapangan memiliki cara tersendiri, yaitu dengan pendekatan persuasif yang tetap beracuan pada penegakan hukum. Akhirnya WP bersedia membayar meskipun sempat salah setor dan dibantu oleh fiskus dalam melakukan pemindahbukuan (Pbk) atas salah setor tersebut.

6. Fiskus perlu menjadwal ulang terkait proses eksekusi WP yang akan dilakukan gijzeling karena ada kegiatan pengajian akbar yang dilaksanakan oleh target operasi. Ketika di lapangan ternyata semua itu bisa berubah, dan itu yang 
benar-benar di luar kewenangan dan kemampuan fiskus.

7. Pengalaman beberapa Juru Sita sering diancam untuk dibunuh oleh WP ketika melaksanakan penagihan pajak. Namun ketika proses gijzeling tahun 2016, pendekatan yang dilakukan lebih persuasif sehingga dapat meminimalisir risiko.

\subsubsection{Dampak yang Timbul}

Aspek pertama, terhadap penerapan gïzeling yang berdampak pada beban kerja fiskus dirasakan oleh 5 (lima) informan, sedangkan 8 (delapan) informan menyatakan tidak ada dampak pada beban kerja karena sudah menjadi bagian dari tugas mereka. Bahkan 2 (dua) informan memberi penjelasan tambahan yang mana tercermin dari sikap informan yang beranggapan bahwa gijzeling memberikan pengalaman berharga buat fiskus sebagai penegak hukum.

Aspek kedua, dampak pada penerapan gïzeling kepada WP yang memiliki tunggakan pajak diakui oleh semua informan. Hasil wawancara menunjukkan dampak yang dirasakan setelah WP/Penanggung Pajak dilakukan gijzeling adalah meningkatnya kepatuhan WP yang dilakukan gijzeling, memiliki dampak positif pada pelunasan utang pajaknya, dan memberikan efek jera terhadap penunggak pajak lainnya untuk melunasi tunggakan pajaknya.

Aspek ketiga, dampak yang timbul dari penerapan sistem akuntansi perpajakan yang mendukung penerapan gijzeling. Sebanyak 10 (sepuluh) informan mengetahui dengan adanya sistem online yang terintegrasi di DJP, memudahkan pekerjaan fiskus terutama dalam pelaksanaan gijzeling. Informan menjelaskan bahwa sistem akuntansi perpajakan dapat membantu pengambilan keputusan fiskus untuk menentukan mulai dari awal sebelum gijzeling dengan cara menyeleksi WP/Penanggung Pajak mana saja yang dapat dikenai gijzeling, sampai dengan tahap pelepasan WP/Penanggung Pajak dari Lembaga Pemasyarakatan (Lapas) dikarenakan sudah melunasi hutang pajaknya.

\subsubsection{Realitas Respons WP Lain/Konsultan Pajak/Akademisi terkait Implementasi Gijzeling di Kanwil DJP Jateng I}

Penerapan gijzeling tentunya memberi dampak langsung berupa efek jera kepada WP yang di-gijzeling. Namun apakah benar implementasi gijzeling juga dapat memberikan dampak kepada WP lainnya? Untuk menjawab pertanyaan tersebut, peneliti berusaha menggali lebih dalam akan realitas respons dari sisi yang berlawanan yaitu WP lainnya, konsultan pajak, dan akademisi.

Peneliti mengkonfirmasi pengetahuan dari informan akan implementasi gïzeling yang terjadi di Kanwil DJP Jateng I. Hasilnya semua informan (4 informan) pernah mendengar berita akan gïzeling oleh Kanwil DJP Jateng I melalui media massa. Tetapi semua informan tidak pernah mendapat 
sosialisasi khusus yang membahas gijzeling oleh Kanwil DJP Jateng I kepada WP lain. Fakta kurang meratanya program sosialisasi yang berkaitan dengan gïzeling membuat sebagian besar masyarakat hanya sebatas mengetahui saja pelaksanaan gijzeling, tetapi kurang memahami kenapa WP sampai dilakukan gijzeling dan prosedurprosedur apa yang dilalui sampai ke tahap gïzeling. Seluruh informan berpendapat bahwa DJP perlu menggiatkan sosialisasi yang berkaitan dengan gijzeling agar masyarakat luas lebih memahami akan penerapan gïzeling pada perpajakan.

Besarnya minat informan terkait sosialisasi tentang gijzeling mencerminkan juga dukungan dari masyarakat akan penerapan gïzeling bagi WP yang tidak patuh akan aturan perpajakan. Hal tersebut terlihat dari persetujuan semua informan (4 informan) terhadap penerapan gïzeling oleh DJP, dengan catatan:

1. Gijzeling harus dilakukan dengan manusiawi dan bekerja sama dengan pihak terkait terutama yang berhubungan dengan medis untuk mengantisipasi apabila terjadi hal yang menimpa kesehatan Penanggung Pajak.

2. Gijzeling dilakukan terhadap WP yang mempunyai tunggakan pajak dan mempunyai kemampuan untuk membayar, artinya harus sangat selektif.

Apakah benar pelaksanaan gïzeling memberi dampak efek jera pada WP lainnya? Terdapat pandangan 2 (dua) informan yaitu WP yang usahanya di bidang desain interior dan kontruksi yang menyatakan bahwa secara psikologi pelaksanaan gïzeling berpengaruh kepada mereka sehingga lebih mawas diri akan masalah yang berkaitan dengan pajak perusahaan mereka.

Apakah pelaksanaan gijzeling memberikan dampak dari segi perilaku kepatuhan WP terkait kewajiban perpajakan kedepannya? Ternyata jawaban dari informan berbeda. 2 (dua) informan dari sisi WP menyatakan bahwa yang bersangkutan akan bersikap lebih terbuka dan akan berusaha mematuhi setiap kewajiban perpajakannya. Namun 2 (dua) informan dari konsultan pajak dan akademisi menjawab bahwa pelaksanaan gijzeling tidak otomatis akan membuat WP lainnya menjadi lebih patuh karena tipe dan karakter WP berbeda-beda.

Adanya pandangan berbeda dari WP lainnya, konsultan pajak, dan akademisi bisa menjadi indikasi bahwa sosialisasi berkaitan dengan gijzeling kepada masyarakat luas masih belum memadai sehingga Kanwil DJP Jateng I harus mencari terobosan baru dalam mengedukasi WP lainnya maupun masyarakat secara luas agar lebih memahami esensi dari gïzeling itu sendiri.

Menurut peneliti, solusi yang dapat dilakukan adalah mengadakan sosialisasi secara massal di KPP Pratama maupun Kanwil DJP Jateng I, mengirimkan informasi dengan media surat kepada WP yang bersangkutan melalui AR yang menanganinya, atau dengan memanfaatkan media sosial yang sekarang dapat menjangkau masyarakat secara luas.

Dalam alur sederhana, peneliti mencoba menggambarkan temuan penelitian dalam 
desain alur kinerja perpajakan, penegakan hukum, agar terjadi peningkatan kepatuhan dan penerimaan pajak, dan respons masukan dari WP lain/Konsultan Pajak/Akademisi pada Gambar 2 di lampiran.

\subsection{Analisis Perbedaan Dampak Sebelum dan Sesudah Implementasi Gijzeling Terhadap Kepatuhan WP yang Di-Gijzeling di Kanwil DJP Jateng I}

4.2.1 Analisis Kasus Gijzeling di KPP

Pratama Semarang Selatan

PT IHM mengalami pasang surut dalam hal kepatuhan perpajakan. PT IHM sejak tahun 2010 sudah memliki tunggakan pajak yang belum dibayar. Berbagai cara sudah dilakukan oleh Juru Sita dalam menagih utang pajak, yaitu dengan mengirimkan Surat Teguran, Surat Paksa, dan Surat Perintah Melaksanakan Penyitaan (SPMP) aset milik WP. Namun, pelunasan yang dilakukan oleh PT IHM sampai dengan batas waktu yang ditentukan tidak signifikan karena hanya pelunasan yang nominalnya kecil yang dibayar. Juru Sita juga telah mengundang penanggung pajak berinisial HI untuk konseling atas utang pajaknya. Hasilnya, penanggung pajak secara lisan maupun komitmen tertulis menyatakan bersedia melunasi hutang pajaknya, baik sekaligus maupun mengangsur. Namun, hal tersebut tidak dilaksanakan oleh WP. Akhirnya, PT IHM dikenakan tindakan gijzeling dan utang pajak dengan total Rp119.454.953,- dibayar lunas.

Setelah pelaksanaan gijzeling, kepatuhan dari WP tersebut semakin meningkat yang tercermin dari cepatnya respons WP ketika ada surat himbauan atau pertanyaan dari fiskus. Hal ini sangat berbeda dengan sikap WP sebelum dikenakan gijzeling dimana beberapa surat dari fiskus atau visit yang dilakukan tidak mendapat respons WP. Kondisi ini menunjukkan bahwa penerapan gïzeling kepada penunggak pajak itu memberikan efek jera kepada WP.

\subsubsection{Analisis Kasus Gijzeling di KPP Pratama Kudus}

a. Kasus 1

PT DTK dalam menjalankan kewajiban perpajakannya terlihat kurang patuh dari awal terdaftar di tahun 2006. Berbagai cara sudah dilakukan oleh Juru Sita dalam menagih utang pajak tersebut yaitu dengan mengirimkan Surat Teguran, Surat Paksa, dan SPMP kepada aset milik WP. Memang PT DTK dapat melunasi utang pajak tersebut, karena nominalnya relatif kecil. Namun ternyata tunggakan dari PT DTK jumlahnya banyak dan apabila diakumulasi menjadi Rp275.838.515,-. Saat dilakukan konseling penagihan, Penanggung Pajak menyampaikan akan menyelesaikan utang pajak PPN tapi tidak untuk PPh. Faktanya, hingga saat usulan gizjeling disampaikan belum terdapat pembayaran apapun. 
Setelah PT DTK dikenakan tindakan gijzeling, total utang pajak sebesar Rp275.838.515,dibayar lunas dan tidak ada tunggakan pajak lagi.

Pascapelaksanaan gijzeling, kepatuhan dari WP tersebut semakin meningkat, terutama dalam hal pembayaran tunggakan pajak. Hal ini terlihat dari STP tahun 2014 yang diterbitkan tahun 2017 juga sudah dilunasi. Berdasarkan data, penerapan gïzeling kepada PT DTK terbukti memberikan efek jera bagi WP yang bersangkutan untuk segera melunasi utang pajaknya.

\section{b. Kasus 2}

PT GPH dalam menjalankan kewajiban perpajakannya sedari awal sudah tidak patuh. Berdasarkan penjelasan dari informan PT GPH tidak pernah melaporkan SPT Tahunannya sama sekali, baru di tahun 2015 dan 2016 mulai melaporkan, tapi dengan status nihil sehingga ada kemungkinan WP tidak menunjukkan potensi yang sebenarnya.

Selain itu, PT GPH juga tidak pernah melaporkan SPT Masa-nya sama sekali. Kewajiban dari PT GPH adalah PPh Pasal 21 yang seharusnya disetor dan dilaporkan setiap bulannya. PT GPH bergerak di bidang usaha perhotelan yang pastinya memiliki banyak pegawai sehingga sangat mengherankan jika perusahaan tersebut tidak pernah melaporkan SPT masa PPh Pasal 21. Hal ini memberi kesimpulan bahwa
PT GPH berusaha menghindari pajak (tax avoidance). Fiskus pun melakukan pengawasan dan penegakan hukum yang menyebabkan tunggakan pajak dengan nominal yang beragam.

Berbagai cara sudah dilakukan oleh Juru Sita dalam menagih utang pajak tersebut yaitu dengan mengirimkan Surat Teguran, dan Surat Paksa yang tidak di tanggapi oleh WP. Upaya penagihan (Sita, Blokir, Pencegahan) sudah dilaksanakan secara maksimal. Ternyata tunggakan dari PT GPH jumlahnya banyak dan apabila di total secara akumulatif sebesar Rp309.840.033,-Akhirnya PT DTK dikenakan tindakan gijzeling dengan utang pajak total sebesar Rp309.840.033,--. Semua telah dibayar lunas dan tidak ada tunggakan pajak lagi untuk PT GPH setelah di gijzeling, dan WP bersedia ikut program Tax Amnesty.

\subsubsection{Analisis Kasus Gijzeling di KPP \\ Pratama Semarang Candisari}

Kepatuhan PT GPP dalam menjalankan kewajiban perpajakan mengalami tren naik turun. PT GPP sejak terdaftar di tahun 2002 sudah memiliki tunggakan pajak yang berasal dari pemeriksaan tahun pajak 2011 s.d 2013.

Berbagai cara sudah dilakukan oleh Juru Sita dalam menagih utang pajak dengan mengirimkan Surat Teguran, Surat Paksa, dan SPMP kepada aset milik WP. Juru Sita juga mengundang Penanggung Pajak SMP 
untuk konseling terhadap utang pajaknya. Namun Penanggung Pajak tidak bersedia hadir di KPP Pratama Semarang Candisari. SMP sebagai Penanggung Pajak bersikap tidak kooperatif untuk melunasi hutang pajaknya sehingga dilakukan gijzeling.

Tapi sampai dengan WP akan dikenai tindakan gijzeling tetap tidak ada iktikad baik dari WP untuk melunasi utang pajaknya. Akhirnya setelah PT GPP dikenakan tindakan gijzeling, total utang pajak sebesar Rp720.072.519,- telah dibayar lunas dan tidak ada tunggakan pajak lagi untuk PT GPP. Pasca pelaksanaan gïzeling, kepatuhan dari WP tersebut semakin meningkat. Hal ini terlihat dari penjelasan informan mengenai pelaporan dan pembayaran WP yang menjadi rutin serta setiap kali ada perubahan data WP aktif menginfokan kepada fiskus, bahkan WP dan penanggung pajaknya ikut program Tax Amnesty juga. Penerapan gïzeling kepada PT GPP terbukti memberikan efek jera bagi WP yang bersangkutan dan mendorong WP untuk bersikap terbuka terhadap fiskus.

\subsubsection{Analisis Kasus Gijzeling di KPP Pratama Semarang Pati}

\section{a. Kasus 1}

CV M adalah WP yang kurang patuh dalam menjalankan kewajiban perpajakannya berdasarkan fakta adanya tunggakan pajak dengan nominal yang beragam sebelum CV M dikenai tindakan gijzeling. Juru Sita sudah berupaya menagih utang pajak tersebut dengan mengirimkan Surat Teguran, dan Surat Paksa. Memang CV M dapat melunasi utang pajak tersebut karena nominalnya relatif kecil. Namun ternyata tunggakan dari CV M jumlahnya banyak. Berdasarkan data yang ada jumlah tunggakan secara akumulatif sebesar Rp604.464.385,-Penanggung Pajak mempunyai kemampuan untuk membayar utang pajaknya namun diragukan itikad baiknya untuk melunasi utang pajak karena sampai dengan usulan gizjeling disampaikan, belum juga ada pembayaran. Akhirnya CV M dikenakan tindakan gïzeling dan utang pajak total sebesar Rp604.464.385,- dilunasi seluruhnya.

Menurut penjelasan dari informan, CV M memanfaatkan program Tax Amnesty sehingga tunggakan yang dibayar adalah tunggakan pokoknya saja, sedangkan bunga dari tunggakan tersebut tidak diperhitungkan. Pascapelaksanaan gïzeling ternyata CV M masih memiliki 1 tunggakan lagi, namun jumlahnya relatif tidak besar sebagaimana tercantum dalam Surat Teguran yang dianggap lunas karena CV M mengikuti program Tax Amnesty. Contoh kasus ini juga membuktikan bahwa penerapan gijzeling terbukti memberikan efek jera bagi WP untuk segera melunasi utang pajaknya.

a. b. Kasus 2

CV AMI dalam menjalankan kewajiban perpajakannya terlihat kurang patuh. CV 
AMI menunggak pajak sejak tahun 2012. Kalaupun ada pembayaran, baru sekitar Rp100 juta dari jumlah tunggakan seluruhnya yang mencapai Rp800 juta. Pokok pajaknya diperkirakan mencapai Rp2,01 miliar. Jumlah tersebut, sudah termasuk tunggakan pajak Rp669.185.103,--. Berbagai cara sudah dilakukan oleh Juru Sita dalam menagih utang pajak tersebut yaitu dengan mengirimkan Surat Teguran, Surat Paksa, dan SPMP kepada aset milik WP. Selain upaya penagihan aktif terhadap penunggak pajak berinisial EW yang merupakan pemilik CV AMI tersebut, juga dilakukan penyitaan aset berupa tanah dan bangunan. Akhirnya CV AMI dikenakan tindakan gijzeling dan utang pajak total sebesar Rp669.185.103,- telah dibayar lunas. Selain itu, ternyata CV AMI masih mempunyai tunggakan pajak lagi yang belum dibayar. Hal itu terlihat dari data yang ada di Sistem Informasi DJP.

Informasi menarik dari informan, WP tersebut sebenarnya sudah ditawari ikut program Tax Amnesty, namun ditolak. Fiskus sudah menjelaskan bahwa jika mengikuti program tersebut, WP tersebut wajib memberitahukan harta kekayaannya. WP tersebut tidak berkenan untuk mengikuti program Tax Amnesty karena Penanggung Pajak berinisial EW mengaku bangkrut. Setelah dilakukan gijzeling, WP pasrah dan tetap melunasi tunggakannya. Penjelasan tambahan dari informan terkait kasus gïzeling CV AMl yaitu ketika ada kasus yang berkaitan dengan perpajakan, sebagian besar WP cenderung untuk mengganti nama/bendera dan mengaku bangkrut. Hal ini merupakan karakteristik dominan dari WP di Pati yang cenderung keras dan tidak taat pajak.

\subsection{Analisis Implementasi Gijzeling Terhadap Efek Jera Bagi WP yang Dilakukan Gijzeling Maupun WP Lain dari Segi Kepatuhan WP dan Pencairan Tunggakan Pajak di Kanwil DJP Jateng I}

4.3.1 Analisis Efek Jera dan Realisasi

Pencairan Tunggakan Pajak di KPP

Pratama untuk Kasus WP yang di-

Gijzeling

Gijzeling pertama kali dilakukan di Kanwil DJP Jateng I pada tahun 2016 dapat dikatakan memberikan efek jera bagi WP yang disandera. WP-WP yang dikenakan tindakan gïzeling di Kanwil DJP Jateng I, akhirnya melunasi utang pajaknya ditambah biaya penagihan pajak, namun ada salah satu kasus terdapat penyesuaian dalam pembayarannya dikarenakan mengikuti program Tax Amnesty. Data realisasi pencairan tunggakan pajak WP yang digijzeling di lingkungan Kanwil DJP Jateng I tersaji pada Tabel 2 dalam lampiran.

\subsubsection{Analisis Efek Jera Bagi WP Lain dari Segi Pencairan Tunggakan Pajak}


Fakta di lapangan atas penerapan gïzeling pada salah satu WP di KPP Pratama Kudus menunjukkan bahwa gïzeling dapat menimbulkan efek jera kepada WP lain yang mempunyai tunggakan pajak. Hal ini tercermin pada penjelasan kasus Grup TS. PT GPH yang merupakan salah satu perusahaan di bawah Grup TS mendirikan beberapa badan usaha dan melakukan berbagai cara tergantung kepentingan modus untuk menghindari pajak, seperti:

1. membuat akte perubahan pengurus dengan pengurus baru, yang merupakan karyawan sendiri dan digaji oleh perusahaan anggota grup tersebut.

2. membuat kesan seolah-olah telah terjadi jual beli bangunan dan inventaris.

3. tidak kooperatif terhadap petugas dalam rangka memberitahukan saldo kekayaan yang tersimpan pada bank.

4. tidak ada itikad baik dalam pelunasan hutang pajak.

Dari keterangan informan, WP lain yang masih satu grup milik TS juga mempunyai banyak tunggakan yang belum dibayar. Dengan adanya data-data yang dimiliki, akhirnya Juru Sita bekerja untuk menggali potensi yang ada, sehingga semua WP di bawah Grup TS melunasi utang pajaknya.

Dari fakta kasus gïzeling yang terjadi, kepatuhan pajak mencerminkan sikap dan perilaku WP yang hampir serupa diutarakan James dan Alley (1999). Dimana James dan Alley (1999) menjelaskan lebih jauh mengenai tax compliance ini lebih merujuk pada bagaimana sikap pembayar pajak yang memiliki rasa tanggung jawab sebagai warga negara bukan hanya sekedar takut akan sanksi dari hukum pajak yang berlaku, sehingga dari kasus ini memperkuat hasil bahwa tindakan gïzeling dapat menimbulkan efek jera kepada WP yang lain. Adapun tampilan daftar dari Grup TS tersaji pada Tabel 3 pada lampiran.

\subsubsection{Analisis Dampak Gïzeling terhadap \\ Pencairan Tunggakan Pajak WP Lain di Lingkungan Kanwil DJP Jateng I}

Peningkatan frekuensi dan mutu penagihan pajak sangat diperlukan mengingat semakin besarnya jumlah tunggakan pajak beberapa tahun ini. Salah satu tugas penting DJP adalah melakukan peningkatan pencairan tunggakan pajak. Data yang menunjukkan besarnya tunggakan serta realisasi tunggakan yang terjadi di Kanwil DJP Jateng I tersaji pada Tabel 4 pada lampiran.

Tabel 5 menggambarkan bahwa ternyata rata-rata tunggakan yang dapat dicairkan hanya sebesar 60,95\% dan menurut Klasifikasi Pengukuran Efektivitas termasuk kriteria kurang efektif. Untuk itu, DJP segera mengambil tindakan untuk mengatasi hal tersebut. Salah satu cara yang dilakukan DJP adalah dengan meningkatkan kepatuhan WP. Peningkatan kepatuhan dilakukan melalui penegakan hukum. DJP telah menetapkan bahwa tahun 2016 ini akan diadakan penegakan hukum, adapun data terkait tindakan penagihan pajak di lingkungan Kanwil DJP Jateng I tersaji pada Tabel 5 dalam lampiran.

Kebijakan gïzeling di tahun 2016 dianggap cukup ampuh untuk meningkatkan penerimaan pajak melalui 
pencairan tunggakan pajak yang terlihat dari hasil analisis extra ordinary penagihan di Kanwil DJP Jateng I tahun 2016 yang menyumbang sebesar Rp454.734.295.830,-Hasil tersebut didapat dari tindakan penagihan aktif mulai dari surat teguran, surat paksa, penyitaan, blokir, pelelangan, pencegahan ke luar negeri, dan gïzeling kanwil DJP Jateng I di tahun 2016. Untuk lebih jelasnya potensi yang di dapat dari extra ordinary penagihan peneliti sajikan dalam bentuk Tabel 6 pada lampiran.

Analisa data di atas sejalan dengan teori kepatuhan pajak oleh James dan Nobes (1997) yang mengemukakan bahwa kepatuhan dapat dijelaskan sebagai tingkatan WP dalam memenuhi hukum pajak. Data-data yang tersaji sebenarnya sudah mengungkapkan tingkatan-tingkatan dalam penagihan pajak, namun apabila ternyata WP masih belum memenuhi kewajibannya, perlu tindakan terakhir yaitu gïzeling sebagai senjata utama dalam penagihan.

Semua aktivitas penagihan oleh fiskus sejalan dengan teori yang diungkapkan oleh Kirchler (2007) dalam teori kerangka slippery slope, yaitu jika kekuasaan otoritas pajak meningkat, pembayaran pajak yang diperkirakan akan meningkat juga. Kekuasaan yang dimaksud disini adalah kewenangan KPP Pratama dalam melaksanakan upaya terakhir dalam penagihan, yaitu gijzeling agar kepatuhan WP meningkat karena adanya penegakan hukum dari fiskus.

\subsubsection{Analisis Perbandingan Kinerja Kegiatan Penagihan Tahun 2015 dan 2016 dengan Adanya Kasus Gijzeling di Lingkungan Kanwil DJP Jateng I}

Untuk melihat keefektifan kinerja penagihan di Kanwil DJP Jateng I, peneliti menganalisis perbandingan kinerja penagihan di tahun 2015 ketika belum ada pelaksanaan gijzeling, dengan tahun 2016 ketika ada pelaksanaan gijzeling. Data terkait kegiatan penagihan terlampir pada Tabel 7 dalam lampiran.

Berdasarkan data Tabel 7, kegiatan penagihan aktif di tahun 2016 mengalami penurunan, hanya pelaksanaan Pelelangan Aset dan Gijzeling yang mengalami peningkatan secara signifikan secara berturut-turut sebesar 177,46\% dan 100,00\%. Berdasarkan data tersebut, peneliti menggali informasi apakah penagihan aktif lainnya kurang begitu efektif dibandingkan dengan penagihan dengan cara gïzeling? Ditemukan fakta bahwa di tahun 2016 Kanwil DJP Jateng I mengalami penurunan tren dari kegiatan penagihan aktif bukannya tanpa sebab, tetapi memang kondisi ketika itu lebih mendorong WP untuk ikut program Tax Amnesty dimana WP dihimbau secara persuasif untuk secara sukarela melaporkan hartanya dan membayar tebusan, dibandingkan dengan cara-cara yang lebih represif. Hal ini tidak berlaku untuk beberapa kasus tertentu seperti gijzeling yang secara ketentuan sudah memenuhi syarat dan harus segera di eksekusi. Jadi 
secara garis besar, program Tax Amnesty turut mempengaruhi kinerja dari penagihan secara keseluruhan di Kanwil DJP Jateng I.

\section{KESIMPULAN}

Pertama, pelaksanaan gïzeling di Kanwil DJP Jateng I sudah berjalan sesuai ketentuan peraturan perundang-undangan yang berlaku, meskipun proses di lapangan perlu adanya adaptasi maupun pengembangan, tetapi tetap beracuan pada prosedur dan aturan.

Kedua, pelaksanaan gïzeling merupakan upaya terakhir yang harus dilakukan secara selektif dan hati-hati, paling tidak terdapat dua syarat (kuantitatif dan kualitatif) yang harus terpenuhi. Fiskus harus mampu membuktikan melalui gelar perkara terlebih dahulu bahwa WP tersebut mempunyai kemampuan untuk membayar utang pajak.

Ketiga, penerapan gijzeling memberi dampak terciptanya kepatuhan pajak dalam hal pembayaran tunggakan pajak, dimana WP segera melunasi utang pajaknya terutama bagi WP yang dikenakan tindakan gijzeling. Hal tersebut terlihat dalam perbedaan dampak sebelum dan sesudah implementasi gijzeling.

Keempat, pelaksanaan gïzeling dapat menciptakan efek jera bagi WP lain yang punya tunggakan pajak yang berada 1 (satu) grup dengan WP yang di güzeling, terlihat pada kasus di KPP Pratama Kudus.
Kelima, pencairan tunggakan pajak melalui gïzeling berhasil terealisir 100\%, namun gïzeling belum berpengaruh terhadap pencairan tunggakan pajak melalui penagihan aktif lainnya terutama kepada WP lain yang memiliki tunggakan pajak. Hal ini bisa disebabkan karena pelaksanaannya bersamaan dengan program Tax Amnesty dimana fiskus mendorong WP untuk ikut program tersebut sehingga WP dihimbau secara persuasif agar secara sukarela melaporkan hartanya dan membayar tebusan, dibandingkan dengan cara-cara yang lebih represif.

\section{IMPLIKASI DAN KETERBATASAN}

Pertama, penelitian dilakukan di KPP Pratama di Kanwil Jateng I yang memiliki kasus gijzeling pada tahun 2016, sehingga data yang digunakan peneliti hanya terbatas di tahun 2016 dan bersamaan dengan program Tax Amnesty. Oleh karena itu, hasil penelitian tidak bisa digeneralisasi terkait penerapan gijzeling di tempat lain maupun penerapan gijzeling di seluruh indonesia.

Kedua, keterbatasan wawancara terletak pada pemilihan pelaku yang menjadi informan. Pelaku yang menjadi informan hanya terbatas pada pelaku yang ada hubungannya dengan kegiatan gïzeling saja. Peneliti juga tidak berhasil mendapat informan utama yaitu WP yang dikenai tindakan gijzeling dalam kasus penagihan pajak. Hambatan tersebut berasal dari 
penolakan ijin dari instansi sebab WP yang dikenakan tindakan gijzeling bersifat rahasia.

Ketiga, keterbatasan informan yang akan diwawancarai. Pada tahun 2017, beberapa fiskus yang menjadi calon informan ternyata banyak yang mengalami mutasi dari kantor yang memiliki kasus gïzeling sehingga peneliti mengalami kesulitan dan membutuhkan waktu ekstra dalam melakukan wawancara.

Keempat, keterbatasan observasi terletak pada pemilihan lokasi dilakukannya observasi. Pelaksanaan observasi tidak bisa dilakukan pada saat tindakan gïzeling dilakukan, tapi terbatas pascapelaksanaan gïzeling dengan menangkap dampak yang terjadi setelah pelaksanaan gijzeling.

Kelima, keterbatasan dalam memperoleh dokumen data gijzeling karena termasuk data yang rahasia. Namun demikian peneliti mencoba mengatasi keterbatasan tersebut dengan triangulasi data melalui analisis hasil wawancara, analisis hasil observasi dan analisis dokumen pendukung.

Rekomendasi bagi penelitian selanjutnya diharapkan melakukan penelitian sesudah tahun 2016, dan memperpanjang periode tahun penelitian sehingga dampak gijzeling terhadap kepatuhan WP akan lebih terlihat.

\section{DAFTAR PUSTAKA}

[1] Becker, G. S. (1968). Crime and punishment: An economic approach. Journal of Political Economy, 76(2), 169-217. https://doi.org/10.1086/259394
[2] Epstein, R. (1998). Imprisonment for debt: The courts and the poll tax. Journal of Social Welfare and Family Law, 2(2), 165-175. https://doi.org/10.1080/09649069808410242

[3] Epstein, R., Masson, I., \& Wise, I. (2011). Imprisonment for debt: a case study. Diakses tanggal $13 \quad$ April 2017 di http://www.alumni.coventry.org

[4] Finlay, L. (2006). Going exploring: The nature of qualitative research. New York: John Wiley and Sons

[5] Gordon, R. K. (1996). Law of tax administration and procedure. In V. T. Thuronyi (Ed.), Tax law design and drafting Vol. 1 (pp. 95-134). International Monetary Fund. https://doi.org/10.5089/9781557755872.071

[6] James, S., \& Alley, C. (1999). Tax compliance, self-assessment and tax administration in New Zealand: Is the carrot or the stick more appropriate to encourage compliance?. New Zealand Journal of Taxation Law and Policy, 5(1), 3-14.

[7] James, S., \& Nobes, C. (1997). The economics of taxation, principle, policy and practice. London: Prentice Hall

[8] Kirchler, E. (2007). The economic psychology of tax behavior. Cambridge: Cambridge University Press.

[9] Kubiak, P. (2012). Imprisonment of tax nonPayers - an abuse of power or a measure of legal discipline?. Studia Ceranea-Journal of the Waldemar Ceran Research Centre for the History and Culture of the Mediterranean Area and South-East Europe, 2, 45-51. http://dx.doi.org/10.18778/2084-140X.02.04

[10] Lucia, C. M. (2009). Efektifitas pelaksanaan Undang-Undang Penagihan Pajak dengan Surat Paksa khususnya pelaksanan pencegahan dan penyanderaan dari perspektif peningkatan penerimaan negara [Tesis tidak dipublikasikan]. Universitas Indonesia.

[11] Miles, M. B., dan Huberman, A. M. (2007). Qualitative data analysis (terjemahan): Jakarta: UI Press. 
[12] Norma, R. K. Z., Ispriyarso, B., Adiyanta, F. C. S. (2016). Penagihan pajak dengan menggunakan sandera pajak (gijzeling) di lingkungan kerja Kantor Wilayah Direktorat Jenderal Pajak Jawa Tengah I dan Kantor Wilayah Direktorat Jenderal Pajak Jawa Tengah II [Skripsi tidak dipublikasikan]. Universitas Diponegoro.

[13] Notoatmodjo, S. (2003). Ilmu kesehatan lingkungan. Jakarta: PT Rineka Cipta.

[14] Nurmantu, S. (2005). Pengantar perpajakan. Jakarta: Granit.

[15] Posner, E. A. (2000) Law and social norms: The case of tax compliance. Virginia Law Review, 86(8),

1781-1819. https://doi.org/10.2307/1073829

[16] Putri, A. Y. 2008. Penyanderaan (gijzeling) sebagai upaya pencairan tunggakan pajak (Suatu tinjauan pelaksanaan penyanderaan pada periode 2003 sampai dengan 2005) [Skripsi tidak dipublikasikan]. Universitas Indonesia.

[17] Rahaviadhy, E. (2004). Tindak penyanderaan Penunggak Pajak oleh Direktorat Jenderal Pajak ditinjau dari sudut penegakan hukum dan peningkatan penerimaan pajak [Tesis tidak dipublikasikan]. Universitas Indonesia.

[18] Rahayu, S. K. (2010). Perpajakan Indonesia. Yogyakarta: Graha IImu.

[19] Robbins, S. P. (2001). Organizational behavior, 14/E: Pearson Education India

[20] Shavell, S. (1985). Criminal law and the optimal use of nonmonetary sanctions as a deterrent. Discussion Paper No. 13/85 Programs in Law and Economics Harvard Law School. http:// www.law.harvard.edu/programs/olin_center/pa pers/pdf/Shavell_13.pdf

[21] Veronica, K., Khairani, S., Fajriana, I. (2015). Analisis penyanderaan pajak (gijzeling) dalam upaya pencairan tunggakan pajak waib pajak badang (studi kasus di KPP Madya Palembang) [Skripsi tidak dipublikasikan]. Sekolah Tinggi Ilmu Ekonomi Multi Data Palembang.

[22] Wahyumurti, M. (2005). Pengaruh lembaga sandera (gijzeling) terhadap tingkat kepatuhan Wajib Pajak/Penanggung Pajak [Tesis tidak dipublikasikan]. Universitas Diponegoro..
[23] Wismono, N. H. (2006). Pelaksanaan penyanderaan (gijzeling) sebagai upaya meningkatkan kesadaran Wajib Pajak [Tesis tidak dipublikasikan]. Universitas Indonesia. 


\section{LAMPIRAN}

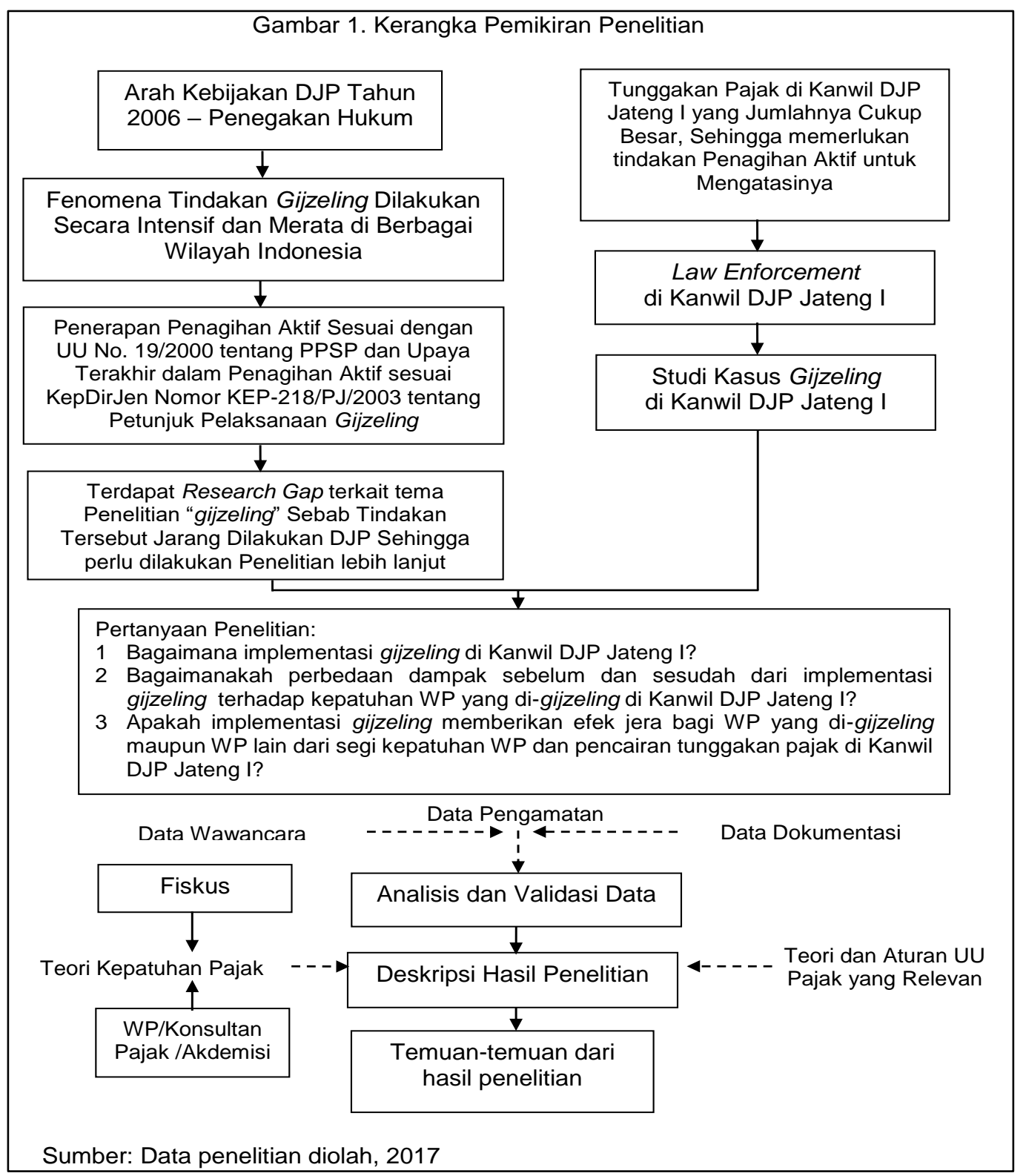




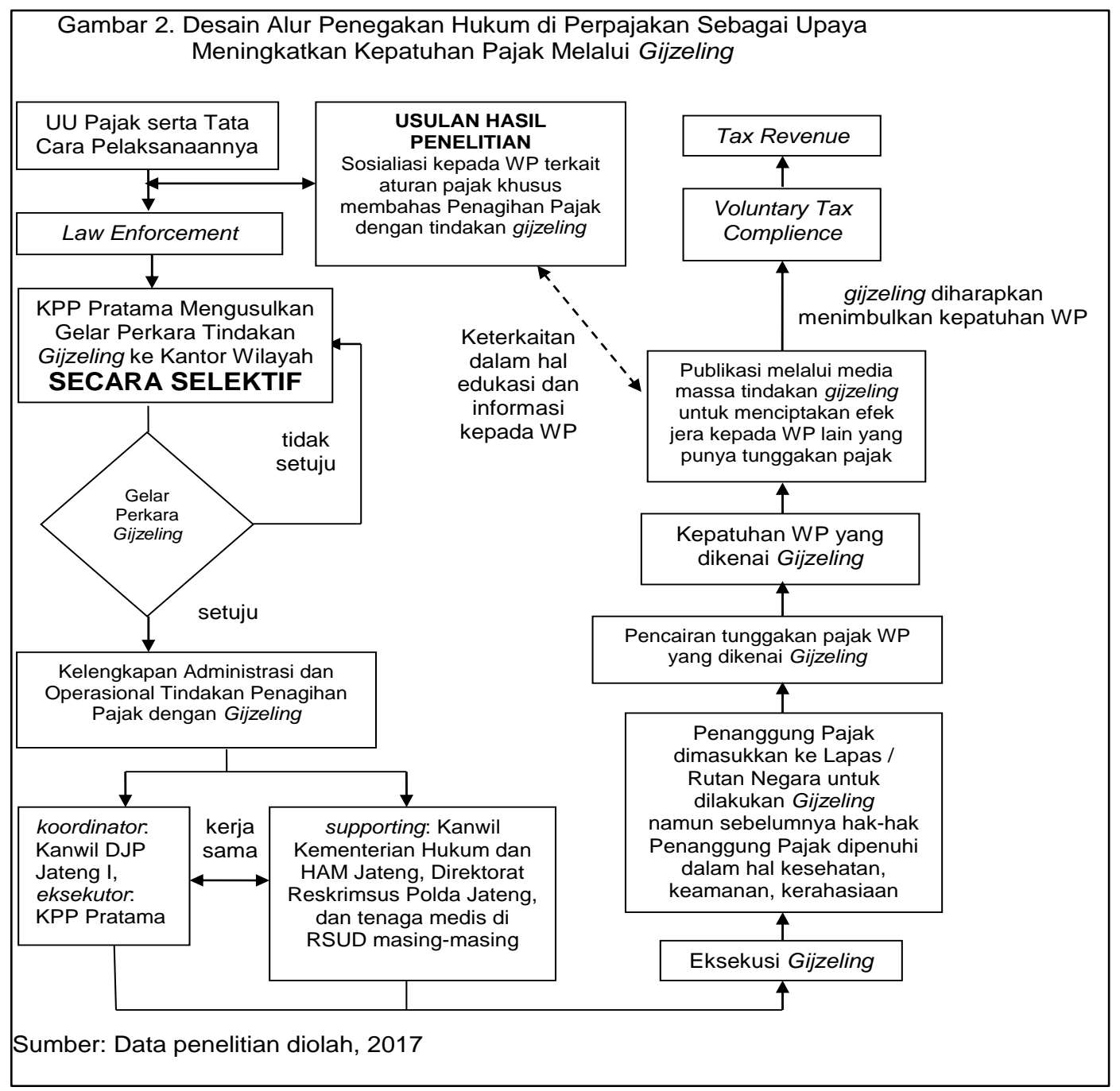


Tabel 1 Usulan Gelar Perkara Penyanderaan s/d 30 Juni 2017 - Kanwil DJP Jateng I Sumber: Kanwil DJP Jateng I, Data diolah (2017)

\begin{tabular}{clcc}
\hline KODE KPP & \multicolumn{1}{c}{ UNIT KERJA } & TARGET & USUL SANDERA \\
\hline 501 & KPP Pratama Tegal & 2 & 2 \\
502 & KPP Pratama Pekalongan & 2 & 2 \\
503 & KPP Pratama Semarang Barat & 2 & 1 \\
504 & KPP Pratama Semarang Timur & 2 & 1 \\
505 & KPP Pratama Salatiga & 2 & - \\
506 & KPP Pratama Kudus & 2 & 1 \\
507 & KPP Pratama Pati & 2 & 1 \\
508 & KPP Pratama Semarang Selatan & 2 & 3 \\
509 & KPP Pratama Semarang Tengah Dua & 2 & 1 \\
511 & KPP Madya Semarang & 2 & 2 \\
\hline 512 & KPP Pratama Semarang Tengah Satu & 2 & - \\
\hline 513 & KPP Pratama Batang & 2 & 2 \\
\hline 514 & KPP Pratama Blora & 2 & 1 \\
\hline 515 & KPP Pratama Demak & 2 & - \\
\hline 516 & KPP Pratama Jepara & 2 & 2 \\
\hline 517 & KPP Pratama Semarang Candisari & 2 & 2 \\
\hline 518 & KPP Pratama Semarang Gayamsari & 2 & $\mathbf{2 2}$ \\
\hline
\end{tabular}

Tabel 2 Realisasi Pencairan Tunggakan Pajak s/d 31 Desember 2016 WP yang di Gijzeling - Kanwil DJP Jateng I

Sumber: Kanwil DJP Jateng I, Data diolah (2017)

\begin{tabular}{|c|c|c|c|c|c|}
\hline No & Unit Kerja & $\begin{array}{l}\sum \text { Kasus } \\
\text { Gijzeling }\end{array}$ & Nama WP/PP & $\begin{array}{c}\text { Nominal Sesuai } \\
\text { Sprindra }\end{array}$ & Nominal Realisasi \\
\hline \multirow{2}{*}{1} & \multirow{2}{*}{ KPP Pratama Kudus } & \multirow{2}{*}{2 Kasus } & PT GPH / SPG & 309.840 .033 & 309.840 .033 \\
\hline & & & PT DTK / S & 275.838 .515 & 275.838 .515 \\
\hline \multirow{2}{*}{2} & \multirow{2}{*}{ KPP Pratama Pati } & \multirow{2}{*}{2 Kasus } & CV M / TTR & 604.464 .385 & 532.139 .040 \\
\hline & & & CV AMI / EW & 669.185.103 & 669.185 .103 \\
\hline 3 & $\begin{array}{l}\text { KPP Pratama } \\
\text { Semarang Selatan }\end{array}$ & 1 Kasus & PT IHM / HI & 119.454 .953 & 119.454 .953 \\
\hline 4 & $\begin{array}{l}\text { KPP Pratama } \\
\text { Semarang Candisari }\end{array}$ & 1 Kasus & PT GPP / SMP & 720.072 .519 & 720.072 .519 \\
\hline \multicolumn{4}{|c|}{ Jumlah } & 2.698 .855 .508 & 2.626 .530 .163 \\
\hline \multicolumn{4}{|c|}{ Selisih *) } & & 72.325 .345 \\
\hline
\end{tabular}

*) Terdapat penyesuaian pembayaran tunggakan karena WP mengikuti program Tax Amnesty 
Tabel 3 Potensi Pencairan Piutang Grup TS

Sumber: Data diolah (2017)

\begin{tabular}{cccccc}
\hline No & Nama WP & Bidang & Piutang Awal & $\begin{array}{c}\text { Piutang Sudah } \\
\text { Daluarsa }\end{array}$ & Saldo Piutang \\
\hline 1 & PT KAJ & Hotel & 1.483 .686 .312 & 1.483 .386 .312 & 300.000 \\
2 & PT GPH & Hotel & 309.840 .033 & & 309.840 .033 \\
3 & PT GBAH & Distributor & 324.411 .326 & 323.061 .326 & 1.350 .000 \\
4 & PT GKT & Distributor & 1.648 .734 .116 & & 1.648 .734 .116 \\
5 & PT JHK & Apotik & 122.633 .416 & 116.784 .541 & 5.848 .875 \\
6 & CV R & Apotik & 369.834 .204 & 313.752 .973 & 56.081 .231 \\
& & & $\mathbf{4 . 2 5 9 . 1 3 9 . 4 0 7}$ & $\mathbf{2 . 2 3 6 . 9 8 5 . 1 5 2}$ & $\mathbf{2 . 0 2 2 . 1 5 4 . 2 5 5}$ \\
\hline
\end{tabular}

Tabel 4 Persentase Realisasi Tunggakan Pajak

Sumber: Kanwil DJP Jateng I, Data diolah (2017)

\begin{tabular}{crrr}
\hline Tahun & Jumlah Tunggakan Pajak & Realisasi Tunggakan Pajak & \% Realisasi \\
\hline $\mathbf{2 0 1 4}$ & 303.392 .000 .000 & 232.880 .618 .295 & $76,76 \%$ \\
$\mathbf{2 0 1 5}$ & 379.240 .000 .000 & 329.141 .532 .163 & $86,79 \%$ \\
$\mathbf{2 0 1 6}$ & 488.235 .789 .686 & 216.396 .291 .972 & $44,32 \%$ \\
Smstr I 2017 & 395.739 .204 .000 & 142.217 .250 .918 & $35,94 \%$ \\
\hline \multicolumn{4}{r}{ Rata-rata } \\
\hline
\end{tabular}

Tabel 5 Tindakan Penagihan Aktif

Sumber: Kanwil DJP Jateng I, Data diolah (2017)

\begin{tabular}{lcccc}
\hline Jenis Penagihan Aktif & $\mathbf{2 0 1 4}$ & $\mathbf{2 0 1 5}$ & $\mathbf{2 0 1 6}$ & Smstr I - 2017 \\
\hline Surat Teguran & 19.255 & 21.017 & 23.265 & 14.985 \\
Surat Paksa & 13.975 & 13.839 & 9.935 & 6.767 \\
Penyitaan & 1.164 & 1.267 & 1.240 & 483 \\
Pelelangan Aset & 26 & 10 & 7 & 6 \\
Pemblokiran & 593 & 383 & 192 & 21 \\
Pencegahan & 15 & 26 & 26 & 6 \\
Penyanderaan & - & - & 6 & - \\
\hline
\end{tabular}


Tabel 6 Extra Ordinary Penagihan di Kanwil DJP Jateng I Tahun 2016

(Data Sudah di Rekonsiliasi)

Sumber: Kanwil DJP Jateng I, Data diolah (2017)

\begin{tabular}{|c|c|c|c|c|c|}
\hline \multirow[t]{2}{*}{ Uraian } & \multicolumn{5}{|c|}{ Pencegahan } \\
\hline & $\begin{array}{l}\text { Tindakan } \\
\text { Pencegahan } \\
\text { ke LN }\end{array}$ & $\begin{array}{c}\text { Dilanjutkan } \\
\text { ke } \\
\text { Penyanderaan }\end{array}$ & $\begin{array}{l}\text { Mengikuti } \\
\text { Tax } \\
\text { Amnesty }\end{array}$ & $\begin{array}{c}\text { Belum Melunasi } \\
\text { Tunggakan } \\
\text { Pajak }\end{array}$ & $\begin{array}{c}\text { Diusulkan } \\
\text { Penyanderaan }\end{array}$ \\
\hline Jumlah PP & 49 & 6 & 4 & 39 & 4 \\
\hline Nilai Tunggakan & 18.365 .151 .270 & 2.626 .530 .163 & 3.505 .597 .573 & 12.233 .023 .534 & 9.535 .620 .618 \\
\hline Pencairan & 1.085 .186 .266 & 2.626 .530 .163 & 1.479 .147 .182 & - & - \\
\hline
\end{tabular}

\begin{tabular}{cccccc}
\hline Uraian & \multicolumn{5}{c}{ Kegiatan Penagihan Aktif } \\
\hline & $\begin{array}{c}\text { Surat } \\
\text { Teguran }\end{array}$ & Surat Paksa & Penyitaan & $\begin{array}{c}\text { Pelelangan } \\
\text { Aset }\end{array}$ & Pemblokiran \\
$\begin{array}{c}\text { Jumlah } \\
\text { Kegiatan }\end{array}$ & 23.265 & 9.935 & 1.240 & 7 & 192 \\
$\begin{array}{c}\text { Nilai } \\
\text { Tunggakan }\end{array}$ & 132.421 .058 .879 & 101.347 .600 .935 & 58.881 .709 .614 & 19.742 .674 .589 & 32.801 .205 .594 \\
Pencairan & 37.479 .642 .278 & 29.304 .954 .458 & 17.216 .450 .423 & 374.178 .124 & 2.056 .221 .107 \\
\hline
\end{tabular}

\begin{tabular}{cccccc}
\hline Uraian & \multicolumn{4}{c}{ Pencairan Tunggakan } \\
\hline & $\begin{array}{c}\text { Dgn Surat } \\
\text { Teguran }\end{array}$ & $\begin{array}{c}\text { Dgn Surat } \\
\text { Paksa, Sita, } \\
\text { Blokir \& Lelang }\end{array}$ & $\begin{array}{c}\text { Pgn } \\
\text { Pencegahan \& }\end{array}$ & $\begin{array}{c}\text { di Luar } \\
\text { Kegiatan } \\
\text { Penagihan } \\
\text { Nenanderan }\end{array}$ & $\begin{array}{c}\text { Jumlah } \\
\text { Pencairan } \\
\text { Tunggakan }\end{array}$ \\
\hline Nilai Pencairan & 37.479 .642 .278 & 48.951 .804 .112 & 3.711 .716 .429 & 364.591 .133 .011 & 454.734 .295 .830 \\
\hline
\end{tabular}

Tabel 7 Kegiatan Penagihan Aktif Kanwil DJP Jateng I

(Data Sudah di Rekonsiliasi)

Sumber: Kanwil DJP Jateng I, Data diolah (2017)

\begin{tabular}{cccccccc}
\hline \multirow{2}{*}{ Tahun } & \multicolumn{7}{c}{ Kegiatan Penagihan Aktif } \\
\cline { 2 - 8 } & Surat Teguran & Surat Paksa & Penyitaan & $\begin{array}{c}\text { Pelelangan } \\
\text { Aset }\end{array}$ & Pemblokiran & Pencegahan & Penyanderaan \\
\hline $\mathbf{2 0 1 5}$ & 161.083 .541 .118 & 107.586 .623 .411 & 41.006 .049 .213 & 134.857 .000 & 31.963 .732 .148 & 2.092 .244 .497 & 0 \\
$\mathbf{2 0 1 6}$ & 37.479 .642 .278 & 29.304 .954 .458 & 17.216 .450 .423 & 374.178 .124 & 2.056 .221 .107 & 1.085 .186 .266 & 2.626 .530 .163 \\
\hline $\begin{array}{c}\text { Per- } \\
\text { tumbu } \\
\text { han }\end{array}$ & $-76,73 \%$ & $-72,76 \%$ & $-58,01 \%$ & $177,46 \%$ & $-93,57 \%$ & $-48,13 \%$ & $100,00 \%$ \\
\hline
\end{tabular}

